\title{
Sinningia allagophylla (Gesneriaceae): in vitro cultivation of a native plant of the Brazilian cerrado
}

\author{
VILMA PALAZETTI DE ALMEIDA ${ }^{1}$ and SIMONE LILIANE KIRSZENZAFT SHEPHERD²,3
}

(recebido em 26/06/98; aceito em 19/05/99)

\begin{abstract}
Sinningia allagophylla (Gesneriaceae): in vitro cultivation of a native plant of the Brazilian cerrado). We used axillary buds as initial explants for hormone interaction studies required for in vitro cultivation of $S$. allagophylla. Callus production was achieved on gelled Murashige \& Skoog medium (MS) supplemented with indole-3-acetic acid (IAA=0.1 and 0.5 mg.1 $1^{-1}$ alone or combined with 6 benzylaminopurine) $\left(\mathrm{BA}=0.01\right.$ and $\left.0.1 \mathrm{mg} \cdot \mathrm{l}^{-1}\right)$. A hormone balance between IAA and BA that would encourage shoot bud development was not found. Nodal segments from axenic cultures grown in the presence of cytokinin $\left(0.1 \mathrm{mg} .1^{-1}\right.$ of BA) without any auxin on MS medium with half-strength macronutrients were used as a standard explant source for subsequent experiments on optimum mineral culture media composition for $S$. allagophylla in vitro cultivation. We found that explants kept in vitro on gelled Gamborg et al. (B5) mineral composition culture medium showed better shoot and specially root growth than on MS medium. Comparisons of the ammonium and nitrate ratios of MS and B5 media indicate that B5 medium has a substantial reduced ammonium ion when compared to MS medium, as well as a lower total nitrogen level. The growth response pattern obtained in vitro may be evidence of the adaptation of this species to soils of poor mineral composition as found in the Brazilian cerrado, as well as an indication that nitrogen levels play a key role for $S$. allagophylla growth.
\end{abstract}

RESUMO - (Sinningia allagophylla (Gesneriaceae): cultivo in vitro de uma planta nativa do cerrado brasileiro). Gemas axilares de plantas coletadas em casa de vegetação foram utilizadas como explantes iniciais para os estudos das interações hormonais visando ao cultivo in vitro de $S$. allagophylla. Calos foram produzidos a partir destes explantes, em meio geleificado de Murashige \& Skoog (MS) suplementado com ácido 3 indol-acético (AIA $=0,1$ e $0,5 \mathrm{mg} .1^{-1}$ ) sozinho ou combinado com 6 benzilaminopurina $\left(\mathrm{BA}=0,01 \mathrm{e} 0,1 \mathrm{mg} \cdot \mathrm{l}^{-1}\right)$. O desenvolvimento de partes aéreas não foi obtido com os balanços hormonais de AIA e BA testados. Para os experimentos subseqüentes de otimização da composição mineral para o cultivo in vitro de $S$. allagophylla, utilizamos como explantes padrões de segmentos nodais de parte aérea de culturas axênicas acrescidas apenas da citocinina (BA a $0,1 \mathrm{mg} .1^{-1}$ ) sem auxina no meio MS, de composição mineral diluída à metade. Observamos que os explantes mantidos em meio geleificado de Gamborg et al. (B5) tiveram melhor crescimento da parte aérea e principalmente das raízes do que aqueles explantes mantidos no meio MS. Comparando-se as razões entre amônio e nitrato dos meios MS e B5 pode-se observar que o meio B5 tem uma redução substancial do íon amônio, assim como um nível de nitrogênio total menor que o meio MS. Desta maneira, o padrão de resposta obtido in vitro atua como evidência da adaptação desta espécie a um solo de composição mineral pobre como o encontrado no cerrado brasileiro, além de ser uma indicação de que níveis de nitrogênio desempenham um papel chave no crescimento de S. allagophylla.

Key words - Cerrado, plant tissue culture, growth regulators, nitrogen levels

\section{Introduction}

The cerrado is the second largest vegetation formation in Brazil, coming second only to the Amazonian forest, and covering about $25 \%$ of the country or approximately 2 million $\mathrm{km}^{2}$ (Ratter \& Ribeiro 1996). Cerrado has a number of peculiar characteristics distinguishing it from other vegetation types, with several authors suggesting that the occurrence of cerrado in a given area depends on a

1. Departamento de Morfologia e Patologia /PUC-SP, Pça Dr. José Ermírio de Moraes, 290, Caixa Postal 1570, 18030-230 Sorocaba, SP, Brazil.

2. Departamento de Fisiologia Vegetal, IB, UNICAMP, Caixa Postal 6109, 13081-970 Campinas, SP, Brazil.

3. Corresponding author: kirszenz @ obelix.unicamp.br complex mixture of climatic and edaphic factors, emphasising the need for ecophysiological, biochemical and molecular studies to reach a better understanding of adaptation mechanisms in native species (Zaidan \& Ribeiro 1995). Micropropagation of such species is an important option since the cerrado is a threatened biome, having become the main agricultural frontier in the country (Ratter et al. 1997). In addition, numerous studies have demonstrated great economic potential of cerrado plants: as foodstuffs - plants supplying fruits, seeds, tubercles, teas, oils and fats; industrial uses - fibres, cork, gums, resins and latex; medicinal uses - more than 100 species used for treatments and cures; ornamentals - the cerrado is rich in ornamental plants with elevated economic potential (Yexküll \& Mutert 1995). 
Sinningia allagophylla (C. Martius) Wiehler (Gesneriaceae), popularly known as "ynambu jety" $(\mathrm{ynambu}=$ partridge, jety $=$ potato $)$ is a perennial herb that grows wild in cerrado vegetation with a wide distribution in the South of Brazil (Chautems 1993). The climate of the region is tropical, with a distinct pattern of wet and dry seasons (Sarmiento et al. 1985). In January, the aerial parts of $S$. allagophylla start to senesce simultaneously with seed dispersion. The plants will be completely dry by the end of March and practically disappear in the dry seasons - autumn and winter (April August). When spring starts, new shoots are formed re-establishing the annual growth cycle. So the success of this species, as well as that of other geophytic species of the cerrado, depends on a subterranean organ in which the dormant buds are protected during the seasons unfavourable for growth. Although S. allagophylla can reproduce through seed, plant growth is very slow (it takes 10 months from plant to flourish in greenhouse conditions). Vegetative propagation was rarely found in the field and attempts to propagate the plant by tuber cuttings under greenhouse conditions were unsuccessful.

To allow vegetative propagation of this endemic species of an endangered vegetation type and to study interesting aspects of the tuberization process, in vitro micropropagation seems to be a promising approach. In this paper, we describe procedures for the in vitro establishment S. allagophylla.

\section{Materials and methods}

Plant material from the field - The tuberous subterranean organ of S. allagophylla was collected from cerrado at the "Reserva Biológica e Estação Experimental de Moji-Guaçu", near the city of Moji-Guaçu, São Paulo, Brazil. The tubers were then kept in pots with soil: sand $(2: 1)$ and maintained in greenhouse. Plant material in the greenhouse - The apical bud was excised after six months of growth in the greenhouse conditions. The decapitated plant was kept for further seven days in the greenhouse before removal of explants. The seven-day period was necessary to allow the development of axillary buds used as explants. Explant sources were carefully selected: 1) basal nodes were not used due to their high contamination levels; 2 ) plants that were flowering or in senescence were completely avoided. Successful shoot production was obtained only when nodal segments containing axillary buds (two per node) were used as explants.

Type 1 explants - Developed axillary buds about $1 \mathrm{~mm}$ long were soaked in a mixture of three anti-oxidants: cysteine $0.0002 \% \mathrm{w} / \mathrm{v}$, ascorbic acid $0.015 \% \mathrm{w} / \mathrm{v}$, citric acid $0.015 \%$ $\mathrm{w} / \mathrm{v}$, and one drop of Tween 20 per $100 \mathrm{ml}$ of distilled water.
The buds were kept in this solution for three hours, and subsequently they were disinfected in a laminar flow chamber with $70 \%$ ethanol for 20 seconds and rinsed three times in sterile water. The final step of this surface sterilisation procedure for the explants consisted of immersing them in a $1 \%$ sodium hypochlorite solution (v/v) for five minutes, followed by rinses in sterile water. Sterilisation efficiency was verified by maintaining them for seven days in Murashige \& Skoog (MS) basal medium (Murashige \& Skoog 1962) solidified with $0.7 \%$ agar supplemented with $2 \%$ sucrose. Only viable and clean type 1 explants were afterwards cultivated in vitro by transferring each one to a flat-bottomed flask ( $8 \mathrm{~cm}$ high, $2 \mathrm{~cm}$ wide) containing a volume of $10 \mathrm{ml}$ of one of the following two media: 1) medium 1 consisted of full strength MS medium supplemented with two levels of indole-3-acetic acid (IAA) $\left(0.1\right.$ or $\left.0.5 \mathrm{mg} .1^{-1}\right)$ in combination with the cytokinin 6-benzylaminopurine (BA) ( 0.01 or $0.1 \mathrm{mg} . \mathrm{1}^{-1}$ ) or 2 ) medium 2 consisted of half-strength macronutrients MS medium supplemented with $0.1 \mathrm{mg} \cdot \mathrm{l}^{-1} \mathrm{BA}$. For all the experiments, ten replicates per treatment were used and all cultures were maintained at $26^{\circ} \mathrm{C}$ under $14 \mathrm{~h}$ photoperiod provided by daylight radiance of $36 \mathrm{mmol} . \mathrm{m}^{-2} \cdot \mathrm{s}^{-1}$ at culture level.

Type 2 explants - Only explants maintained in medium 2 had developed aerial shoots of about 5 to $10 \mathrm{~cm}$ after two months of in vitro cultivation of type 1 explants. Nodal stem segments $(1 \mathrm{~cm}$ long) with one or two leaves were taken from those aseptically grown plantlets and then used as type 2 explants.

Nutritional experiments - All the nutritional experiments were done with type 2 explants at different concentrations of ammonium and nitrate: full-strength MS medium, full-strength B5 and half-strength B5 (Gamborg et al. 1968). The aerial dry weight and root dry weight were measured after four months of in vitro cultivation at $26^{\circ} \mathrm{C}$ under $14 \mathrm{~h}$ photoperiod conditions.

\section{Results and Discussion}

Plant regeneration for many species cultured in vitro depends on an initial callus stage. Variation in auxin/citokinin ratios promotes different developmental responses. Relatively high concentration of IAA favors cell proliferation and root differentiation whereas higher levels of adenine or kinetin promote bud differentiation (Bhojwani \& Razdan 1983). The axillary buds of S. allagophylla developed calli and roots in MS medium supplemented with IAA. The kind of differentiation obtained with type 1 explants of S. allagophylla in MS medium supplemented with various combinations of IAA and BA can be seen in figure 1 along with percentage data presented in table 1 . Callus and roots proliferation could be seen 20 to 30 days (this was the range of time found after four repetitions of the same procedure) after inoculation in media with IAA alone $\left(0.1\right.$ and $\left.0.5 \mathrm{mg} . \mathrm{l}^{-1}\right)$ or combined with BA $\left(0.01\right.$ and $\left.0.1 \mathrm{mg} . \mathrm{l}^{-1}\right)$. The gene- 


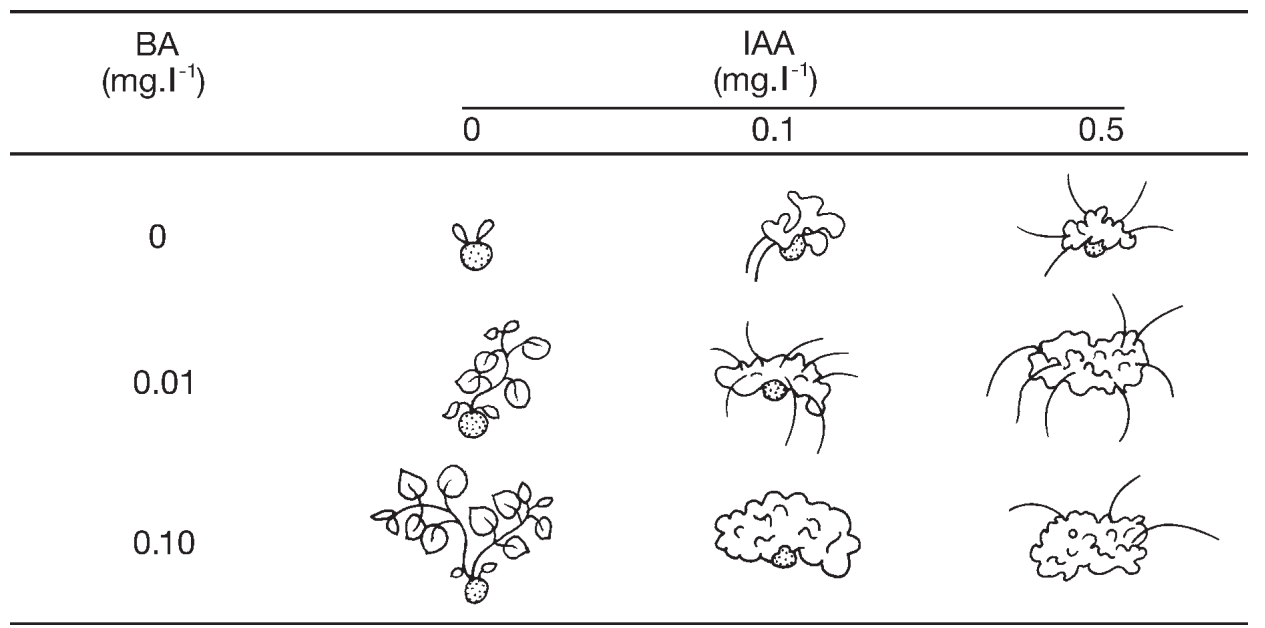

Figure 1. Visual aspects of type 1 explants developed from axillary buds of S. allagophylla cultivated on MS basal medium supplemented with IAA and BA after 30 days of cultivation. Cultures were maintained at $26^{\circ} \mathrm{C}$ under $14 \mathrm{~h}$ photoperiod provided by daylight radiance of $36 \mathrm{mmol} . \mathrm{m}^{-2} \cdot \mathrm{s}^{-1}$ at culture level. Three other experiments performed on different occasions gave similar results.

ral morphogenesis pattern shown in figure 1 was found in all four repetitions.

Higher BA proportion in presence of IAA did not result in any development of shoot buds, an indication that IAA inhibited shoot development. Shoot development was only observed on media containing BA alone. In S. allagophylla cultures an ideal hormone balance between IAA and BA that would promote both shoot bud and root development was not found. Therefore shoots from axenic cultures grown in MS supplemented with $0.1 \mathrm{mg} . \mathrm{l}^{-1} \mathrm{BA}$ were used as an explant source for optimization experiments.

In the literature a large number of different culture media are described differing mainly in mineral nutrition. One of the most important components of the basal medium is nitrogen. In general, because of its toxicity there is a tendency to use lower levels of $\mathrm{NH}_{4}^{+}$than $\mathrm{NO}_{3}^{-}$in plant tissue culture media (Franklin \& Dixon 1994). For type 2 explants of $S$. allagophylla the effect of different basal media, MS, B5 and half strength B5 on dry matter of shoots and roots can be seen in table 2 . In B5 medium (full and half-strength) roots grew better achieving higher dry weight values than roots in MS medium.

In Urtica dioica, low nitrogen supply favoured dry matter formation of the root plus rhizome fraction, whereas high nitrogen supply resulted in a preferential growth of the leaf plus stalk fraction (Rosnitschek-Schimmel 1982). Kerbauy (1993) observed an increase in the development of the orchid root system when explants were submitted to nitrogen deficiency. The increase in dry matter of roots that was observed in S. allagophylla in B5 medium could be a consequence of the substantial

Table 1. Effect of IAA x BA concentrations on callus formation, shoot and root initiation from axillary buds (type 1 explants) of $S$. allagophylla. Percentages shown represent mean of five explants per treatment. Data were recorded after 30 days of inoculation in MS medium.

\begin{tabular}{|c|c|c|c|c|c|c|}
\hline \multirow{2}{*}{$\%$} & \multirow[t]{2}{*}{$\begin{array}{c}\text { BA } \\
\left(\mathrm{mg} \cdot 1^{-1}\right)\end{array}$} & \multicolumn{4}{|c|}{$\begin{array}{c}\text { IAA } \\
\left(\mathrm{mg} .1^{-1}\right)\end{array}$} & \\
\hline & & 0 & 0.1 & & 0.5 & \\
\hline & 0 & 0 & & 0 & & 0 \\
\hline \multirow[t]{3}{*}{ Shoot } & 0.01 & 40 & & 0 & & 0 \\
\hline & 0.1 & 100 & & 0 & & 0 \\
\hline & 0 & 0 & & 20 & & 60 \\
\hline \multirow[t]{3}{*}{ Root } & 0.01 & 0 & & 60 & & 50 \\
\hline & 0.1 & 0 & & 0 & & 20 \\
\hline & 0 & 0 & & 0 & & 60 \\
\hline \multirow[t]{2}{*}{ Callus } & 0.01 & 0 & & 60 & & 100 \\
\hline & 0.1 & 0 & & 80 & & 100 \\
\hline
\end{tabular}


Table 2. Dry matter of shoots and roots (mg) after four months of in vitro cultivation from type 2 explants of $S$. allagophylla. Cultures were maintained at $26^{\circ} \mathrm{C}$ under $14 \mathrm{~h}$ photoperiod provided by daylight radiance of $36 \mathrm{mmol} \cdot \mathrm{m}^{-2} \cdot \mathrm{s}^{-1}$ at culture level. Data represents means of five explants per treatment. Means within line followed by the same letter do not differ significantly at $\mathrm{p}=$ 0.05 as determined by Tukey's HSD test.

\begin{tabular}{lccc}
\hline & MS & \multicolumn{2}{c}{ B5 } \\
\cline { 3 - 4 } Part & $\begin{array}{c}\text { full } \\
\text { strength }\end{array}$ & $\begin{array}{c}\text { full } \\
\text { strength }\end{array}$ & $\begin{array}{c}\text { half } \\
\text { strength }\end{array}$ \\
\hline Aerial & $17.06 \mathrm{a}$ & $23.97 \mathrm{a}$ & $17.69 \mathrm{a}$ \\
Roots & $1.17 \mathrm{a}$ & $4.49 \mathrm{~b}$ & $3.1 \mathrm{~b}$ \\
\hline
\end{tabular}

reduction of ammonium ion in $\mathrm{B} 5$ medium when compared to MS medium. This may suggest a deleterious effect of ammonium ion in this species. In Atropa belladonna the presence of high levels of ammonium ions in media favours the development of incipient plants rather than roots (Thomas \& Street 1972). The deleterious effects of high concentrations of ammonium in plants have already been shown by Gamborg et al. (1968). In Salix (Letouzé \& Daguin 1983) and shoot tip cultures of Amelanchier arborea (Brand 1993) higher concentrations of ammonium nitrate in the medium resulted in an enhancement of hyperhydricity.

In spite of several indications on the toxic effects of ammonium, a series of reports has shown that a minimal amount of endogenous ammonium is essential for embryogenesis in cultured cells as has been shown by Kerbauy (1993) for protocorm regeneration in Oncidium varicosum.

Gigon \& Rorison (1972) observed herbaceous species adapted to different nitrogen sources. These authors reported that various calcifuge herbaceous plant species grow better on ammonium than on nitrate whereas with some calcicoles the inverse is observed. Although single nitrogen sources were not tested in the experiments with Sinningia allagophylla tissue culture, comparisons of the results observed between ammonium and nitrate ratios showed that best growth for tissues of this species was obtained in the poorer B5 medium, which has lower total nitrogen levels than in MS medium. This may indicate adaptation of this species to the nutrient-poor Brazilian cerrado soil, but further studies are necessary to test this hypothesis.
Acknowledgements - Authors thank the Departamento de Fisiologia Vegetal, Instituto de Biologia, Universidade de Campinas (UNICAMP), SP, Brazil for facilities provided. V.P. de Almeida thanks CAPES for financial assistance.

\section{References}

BHOJWANI, S.S. \& RAZDAN, M.D. 1983. Plant tissue culture: Theory and practice. Developments in Crop Science (5). Elsevier Science Publishers, Amsterdam, p. 71-90.

BRAND, M.H. 1993. Agar and ammonium nitrate influence hyperhydricity, tissue nitrate and total nitrogen content of serviceberry (Amelanchier arborea) shoots in vitro. Plant Cell, Tissue and Organ Culture 35:203-209.

CHAUTEMS, A. 1993. Gesneriaceae. In Flora del Paraguay (R. Spichiger \& G. Bocquet, eds.). Conservatoire et Jardins Botaniques Genève, 22, p. 41.

FRANKLIN, C.I. \& DIXON, R.A. 1994. Initiation and maintenance of callus and cell suspension cultures. In Plant Cell Culture: A Pratical Approach - Second Edition (R.A. Dixon \& R.A. Gonzales, eds.). The Practical Approach Series, I.R.L. Press, Oxford, p.1-25.

GAMBORG, O.L., MILLER, R.A. \& OJIMA, K. 1968. Nutrient requirements of suspension cultures of soybean root cells. Experimental Cell Research 50:151-158.

GIGON,A.\& RORISON, H. 1972. The response of some ecologically distinct plant species to nitrate and to ammonium-nitrogen. Journal of Ecology 60:93-102.

KERBAUY, G.B. 1993. Indução in vitro de protocormóides em raízes de Oncidium varicosum. Efeitos de fontes nitrogenadas, auxinas e citocininas. Revista Brasileira de Botânica 16:1-8.

LETOUZÉ, R. \& DAGUIN, F. 1983. Manifestation spontanée et eléatoire d'une croissance anormale en culture in vitro. Recherche de marquerus métaboliques. Revue Canadienne de biologie experimentelle 42:23-28.

MURASHIGE, T. \& SKOOG, F. 1962. A revised medium for rapid growth and bioassays with tobacco tissue culture. Physiologia Plantarum 15:473-497.

RATTER, J.A. \& RIBEIRO, J.F. 1996. Biodiversity of flora of the cerrado. In Anais /Proceedings of the VIII Simpósio sobre o cerrado/ $1^{\text {st }}$ International Symposium on Tropical Savannas (R.C. Pereira \& L.C.B. Nasser, eds.) Embrapa/CPAC, Planaltina, p.3-6.

RATTER, J.A., RIBEIRO, J.F \& BRIDGEWATER, S. 1997. The Brazilian cerrado vegetation and threats to its biodiversity. Annals of Botany 80:22-230.

ROSNITSCHEK-SCHIMMEL, I. 1982. Effect of ammonium and nitrate supply on dry matter production and nitrogen distribution in Urtica dioica. Zeitschrift fur Pflancerphysiologie 108 S:329-341.

SARMIENTO, G., GOLDSTEIN, G. \& MEINZER, F. 1985. Adaptative strategies of woody species in neotropical savannas. Biological Review of the Cambridge Phisiological Society 60:315-355.

THOMAS, E. \& STREET, H.E. 1972. Factors influencing morphogenesis in excised roots and suspension cultures of Atropa belladona. Annals of Botany 36:239-247.

YEXKÜLL, H.R. \& MUTERT, E. 1995. Global extent, development and economic impact of acid soils. Plant Soil 171:1-15.

ZAIDAN, L.R.P. \& RIBEIRO, R.C.F. 1995. Aproveitamento econômico de espécies nativas. Relatório do Workshop "Bases para a conservação e uso sustentável das areas de cerrado do estado de São Paulo", Probio-SMA, São Paulo, p.47. 